\title{
Factors associated with the incidence of malaria in settlement areas in the district of Juruena, Mato Grosso state, Brazil
}

\author{
Fatores associados à incidência da malária em área de assentamento, \\ município de Juruena, Mato Grosso, Brasil
}

Irani Machado Ferreira ${ }^{1}$

Edna Massae Yokoo ${ }^{2}$

Reinaldo Souza-Santos ${ }^{3}$

Noemi Dreyer Galvão ${ }^{1}$

Marina Atanaka-Santos ${ }^{4}$
${ }^{1}$ Secretaria de Estado de Saúde de Mato Grosso.

Centro Político Administrativo, Palácio Paiaguas, Bloco D. 78049902 Cuiabá Mato Grosso. iranimachado@terra.com.br ${ }^{2}$ Departamento de Epidemiologia e

Bioestatística, Centro de

Ciências Médicas,

Universidade Federal

Fluminense.

${ }^{3}$ Departamento de Saúde

Coletiva, Instituto de Saúde

Coletiva, Universidade

Federal de Mato Grosso.

${ }^{4}$ Departamento de

Endemias Samuel Pessoa,

Health Escola Nacional de Saúde Pública Sergio

Arouca, Fundação Oswaldo

Cruz.
Abstract Factors associated with the incidence of malaria in the Vale do Amanhecer settlement, Juruena, Mato Grosso in 2005 were analyzed. Two hundred settlers of both genders and aged 18 years and above were interviewed. The prevalence of malaria reported in 2005 was 33\%. The prevalence ratio showed that the highest prevalence of malaria was found in individuals involved in gold mining activities (67\%); who came from non-endemic areas (43\%); had inadequate knowledge about the time of greatest activity of the vector (71\%); and who reported being outside after 5 p.m. (59\%). It was concluded that in the Vale do Amanhecer settlement, factors such as occupation, origin, inadequate knowledge about where malaria is transmitted, inadequate knowledge about the time the mosquito usually bites and individual practices in relation to the peak period of mosquito activity were associated with malaria in 2005.

Key words Epidemiology, Malaria, Settlement, Socio-demographic factors, Knowledge and Practice
Resumo Analisaram-se fatores associados à ocorrência da malária no Assentamento Vale do Amanhecer, Juruena - Mato Grosso em 2005. Foram entrevistados 200 indivíduos assentados, de ambos os sexos e idade igual ou superior a 18 anos. A prevalência de malária referida em 2005 foi de $33,0 \%$. A análise através da razão de prevalência mostrou que as maiores prevalências de malária foram nos individuos que exerciam atividade garimpeira (67,0\%); procedentes de área não endêmica (43,0\%); com conhecimento inadequado sobre o horário de maior atividade do vetor $(71,0 \%)$ e indivíduos que referiram estar na roça após as 17:00 horas (59,0\%). Concluiu-se que no Assentamento Vale do Amanhecer fatores como, ocupação, procedência, conhecimento inadequado sobre onde a malária é transmitida, horário que o mosquito costuma picar, e as atividades de cada indivíduo em relação ao horário de pico do vetor, mostraram-se associadas à malária em 2005. Palavras-chave Epidemiologia, Malária, Assentamento, Fatores sociodemográficos, Conhecimento e prática 


\section{Introduction}

Malaria is one a major public health problem because both the pathogenic agents and the vectors are found in areas where almost half of the world's population lives. It affects more than three hundred million individuals per year. It severely impacts the African continent and affects more than one million people per year in the Amazon countries in South America. Brazil accounts for one-third of the reported malaria cases ${ }^{1}$. Almost all cases come from the geographic area known as Legal Amazon, and they occur in recent settlements in rural areas where activities are related to gold mining, forestry, and soil preparation for agriculture and mineral exploration ${ }^{2}$.

Malaria in the Mato Grosso State in the Legal Amazon region has been a prominent public health problem since the 80 s and 90 s when a significant number of cases were recorded. During this period, a higher concentration of cases was observed in the extreme west of the state, mainly in areas of recent occupation and in open gold mines. In 1992, the state reached an IPA (annual parasitemic index) of 96.1 per thousand inhabitants. From 1993 to 2002, a marked reduction of the IPA occurred, decreasing to 2.7 cases per thousand inhabitants in $2002^{3}$. Since 2003, the prevalence of the disease has increased, mainly in the extreme west of the state. In 2004, the municipality of Juruena detected 720 blood smears positive for malaria, which corresponded to an IPA of 116.8 per thousand inhabitants; this representing an increase of $184.9 \%$ in the incidence of positive blood smears in relation to 2003 when the IPA was $41.0 / 1,000$ for inhabitants.

In the state of Mato Grosso, there is a high occurrence of malaria in the population that is living in endemic areas, settlements and in individuals with rural occupations. Thus, it is essential to identify the factors involved in disease transmission in places of high occurrence to improve programs of surveillance and control of malaria. This study aims to analyze factors associated with the occurrence of malaria in the Vale do Amanhecer settlement, Juruena, Mato Grosso, Brazil.

This study is part of the research project entitled "Social, economic and cultural aspects involved in malaria production: Applicability of the Guide Manual for Rapid Assessment, recommended by WHO and developed by the Teams of the Family Health Program in the municipality of Juruena (Mato Grosso), 2005”.

In 2004, malaria was the leading cause of communicable disease in the municipality of Jurue- $\mathrm{na}^{4}$. Among the probable places of infection in the municipality, the priority for this study was the Vale do Amanhecer settlement. In this settlement, $96.4 \%$ and $73.7 \%$ of the blood smears were positive for malaria in 2003 and 2004, respectively, being the highest parasite incidences in the Municipality. In 2004, 537 positive blood smears were reported with an IPA of 719.8 per thousand inhabitants. This represents a $247.4 \%$ increase compared to 2003 (IPA 290.9/1,000 hab.), thus indicating an event in an epidemic process ${ }^{4}$.

\section{Materials and methods}

This paper presents results of a cross-sectional study that was conducted in the Vale do Amanhecer settlement, municipality of Juruena, Mato Grosso in 2005. This municipality is located in the northwest region of the state (Figure 1) and is more than $800 \mathrm{~km}$ far from Cuiabá (capital of the state) in the middle of the Amazon forest, with a land area of $3,368.81 \mathrm{~km}^{2}$. The population of the municipality for the year 2005, according to IBGE (Brazilian Institute of Statistics and Geography) estimates, was of 6,216 inhabitants (4,344 in urban and 1,872 in rural areas). The demographic density for the period was 1.85 inhabitants $/ \mathrm{km}^{2}$.

Created by INCRA in 1998, the Vale do Amanhecer settlement has 14.4 thousand hectares. It is located $6.2 \mathrm{~km}$ far from of the urban area of the municipality, and the main access road is the MT - 208 Juruena - Juara. The first families settled in the area in the year 2000. In the same year, a gold extraction company was created in the public environmental reserve (Mineradores Couros) ${ }^{5,6}$. The disorganized gold extraction deforested part of the forest, polluted rivers and opened caves in the land, thereby degrading the environment ${ }^{5}$.

This study area was selected because in 2004 presented the highest parasite incidences in the Municipality of Juruena, also it was considered the facilities for collecting data, because the roads to reach this settlement was not so far from the urban area of the municipality. Furthermore, the local Family Health Program in 2005 assisted $100 \%$ of the individuals in the studied settlement facilitating the research development in this area.

The research sample enrolled 200 families that had settled in the area by November 2005, and the estimate population was approximately 750 inhabitants. The studied sample was based on convenience ${ }^{7}$ in which all the occupied household units of the Vale do Amanhecer settlement were 
Picture 1. Vale do Amanhecer Settlement, Municipality of Juruena, State of Mato Grosso, Brazil, 2005

included during the period of the interviews. Two hundred individuals living in the Vale do Amanhecer settlement were interviewed (one person per household). This individual with age greater than 18 years old, independently of the gender was responsible for the household at the time of the interview.

Data collection was carried out through interviews using a questionnaire that was based on the "RAP" - Rapid Assessment Procedure - method proposed by the Guide Manual for Rapid Assessment of social, economic and cultural aspects involved in the malaria production, published by $\mathrm{WHO}^{8}$, with some adjustment to account for the reality of the municipality of Juruena. Formal interviews were conducted based on a semi-structured questionnaire composed of open and closed questions. The questionnaire was subdivided into two parts: I - Family Information and II - Individual Information. For this study, the "Individual Information" was prioritized.

A pre-test among the community healthcare agents working in the municipality was carried out to determine the clarity and sensitivity of the instrument, and criticism and suggestions for improvement were solicited. The interviewers were trained to standardize the $p$ obtain information, formulate que out the questionnaire.
The interviews were conducted in each settler's household after receiving the participant's permission, by the researchers themselves and the health agents that control malaria in the municipality from $28 / 11 / 2005$ to $02 / 12 / 2005$. Those in charge of the research followed the data collection during all period in order to clarify doubts and to check the quality of the questionnaire applied by the interviewers.

The malaria diagnose was self-reported by the interviewees independently of the episode number in the year of 2005. In the analysis the selfreported malaria was considered the dependent variable (yes $=1$ and no $=0$ ) and the independent variables were: socio-demographic characteristics (age, education level, occupation, origin, monthly family income and housing condition), individual knowledge about the mechanisms of disease transmission, individual practices related to exposure to and protection from malaria.

The distribution of the absolute and relative frequency of the variables was analyzed. Bivariate analyses were conducted in which prevalence ratios (PR) were calculated with 95\% confidence intervals (CI) to examine the significance of the associations between the independent variables and rearia. The results were considered statisficant when the 95\% confidence interthe PRs did not include unity (i.e., 1). 
The research project was approved by the Research Ethics Committee of the University Hospital Júlio Müller, Federal University of Mato Grosso and the researchers obtained written permission from the participants.

\section{Results}

Two hundred individuals were interviewed: $67.0 \%$ were between 32 and 59 years (means 45.1; $\mathrm{SD}=16.8) ; 64.0 \%$ were female; $54.5 \%$ with one to three years of study; $67.0 \%$ were farmers/agricultural workers (of these $52.0 \%$ were female); $66.5 \%$ were from endemic areas (Legal Amazon); $65.5 \%$ had a monthly family income less than a the Brazilian's minimum salary in 2005 (U\$ 137.61 ); $58.5 \%$ lived in houses made of bricks; $52.0 \%$ lived in houses with 1 to 3 people; $83.0 \%$ of the households had bathrooms in the house; and $80.5 \%$ bathed in their own bathroom in their own house. Regarding knowledge and individual practices in relation to malaria: $70.5 \%$ said that they knew how malaria is transmitted; $56.0 \%$ identified the mosquito as the disease vector; $73.0 \%$ were usually out of the house (fields, garden, backyard, corral) very early in the morning; $60.0 \%$ were out of the house late in the afternoon; 78.0\% usually had a bath after 6 P.M; and $88.0 \%$ did not use any kind of protection to sleep.

The prevalence of malaria in 2005 was $33.0 \%$. In relation to the socio-demographic characteristics (Table 1), the prevalence of the disease was higher in the economically active age group. The observed prevalence ratio in the age group from 46 to 59 years old was 4.4 (95\% CI: $1.14-17.27$ ) compared with the prevalence in the age group of 60 years old and more. Regarding occupation, there was a higher prevalence $(67.0 \%)$ among gold miners. The prevalence among individuals that worked in mineral extraction was $92 \%$ higher than among house workers (95\% CI: $1.05-3.50)$. The prevalence of malaria was higher among individuals that were from non-endemic areas (43.0\%). The prevalence ratio of those who came from non-endemic areas was 1.56 (95\% CI: $1.06-2.29)$ when compared with those from the endemic area. In relation to the building material of the houses, there was a higher prevalence of the disease among individuals who lived in black canvas houses or wooden leftovers (62.5\%). The prevalence among people who lived in huts made of black canvas or wooden leftovers was $103.0 \%$ higher than those living in houses made of bricks (PR: 2.03; 95\% CI: $1.11-3.71)$, indicating a statistically significant association between the building material of the house and malaria in 2005.

There was a higher prevalence of malaria among the individuals that said they knew how malaria is transmitted (38.3\%). There was a lower occurrence of the disease among individuals that did not know how malaria is caught ( $\mathrm{PR}=$ 0.53 ; 95\% CI: $0.31-0.92$ ), indicating that this group tends to show a lower prevalence of malaria when compared to those that know how the disease is transmitted. However, among the individuals that believed that the mosquito usually bites all day and all night, the prevalence of malaria was $177.0 \%$ higher compared to those that knew that it was very early in the morning and at twilight (95\% CI: $1.79-4.29)$. Individuals that said that malaria can be transmitted anywhere, had the prevalence $146 \%$ higher than those who said it was in the river or in the forest. These results indicate a positive, statistically significant association between reported malaria and inadequate knowledge regarding the time that the mosquito bites and where malaria can be transmitted. Not knowing how the disease is transmitted and the places where the mosquito comes from presented a negative association with reported malaria (Table 2).

In relation to the individual practices of exposure and protection (Table 3), the prevalence rate of malaria was $125 \%$ higher among individuals that were usually in the field/garden after 5 P.M. (PR = 2.25; 95\% CI: 1.36 - 3.73) compared to individuals that remained in the house. The prevalence of the disease among individuals who had the habit of bathing after 6 P.M. was 2.04 times (95\% CI: $1.06-3.95)$ of those who usually had a bath before 5 P.M. Considering individual practices variables analyzed, only individuals in the field in the afternoon and bathing after 6 P.M. were statistically associated with malaria in 2005.

\section{Discussion}

In the study area, the prevalence rate of reported malaria was $33.0 \%$. In the bivariate analyses, the factors associated with the occurrence of malaria in the Vale do Amanhecer settlement in 2005 were examined, including variables related to age, occupation, origin, knowledge about the mechanisms of malaria transmission (the time mosquitoes usually bite and the locations where malaria is transmitted), and individual practices (frequency in the fields/gardens after 5 P.M. and the time when baths were taken). 
Table 1. Socio-demographic factors and prevalence rates (PR) of malaria reported in 2005, Vale do Amanhecer settlement, municipality of Juruena, Mato Grosso, Brazil.

\begin{tabular}{|c|c|c|c|c|c|}
\hline \multirow{3}{*}{ Variables } & \multicolumn{4}{|c|}{ Reported Malaria - 2005} & \multirow{3}{*}{ PR $(95 \%$ CI $)$} \\
\hline & \multicolumn{2}{|c|}{ Yes } & \multicolumn{2}{|c|}{ No } & \\
\hline & $\mathbf{n}$ & $\%$ & $\mathbf{n}$ & $\%$ & \\
\hline \multicolumn{6}{|l|}{ Age } \\
\hline$\geq 60$ or above & 2 & 9.0 & 20 & 91.0 & 1.00 \\
\hline $46-59$ & 23 & 40.0 & 34 & 60.0 & $4.44(1.14-17.27)$ \\
\hline $32-45$ & 28 & 36.0 & 49 & 64.0 & $4.00(1.03-15.44)$ \\
\hline $18-31$ & 13 & 30.0 & 31 & 70.0 & $3.25(0.80-13.15)$ \\
\hline \multicolumn{6}{|l|}{ Gender } \\
\hline Female & 48 & 37.5 & 80 & 62.5 & 1.00 \\
\hline Male & 18 & 25.0 & 54 & 75.0 & $0.67(0.42-3.92)$ \\
\hline \multicolumn{6}{|l|}{ Education Level } \\
\hline$>4$ years & 21 & 29.0 & 51 & 71.0 & 1.00 \\
\hline$<3$ years & 42 & 39.0 & 67 & 61.0 & $1.32(0.86-2.03)$ \\
\hline Illiterate & 3 & 16.0 & 16 & 84.0 & $0.54(0.18-1.62)$ \\
\hline \multicolumn{6}{|l|}{ Current Occupation } \\
\hline Housewife & 17 & 35.0 & 32 & 65.0 & 1.00 \\
\hline Farmer/agricultural worker & 43 & 32.0 & 91 & 68.0 & $0.92(0.59-1.46)$ \\
\hline Mining Activity & 6 & 67.0 & 3 & 33.0 & $1.92(1.05-3.50)$ \\
\hline Others & - & - & 8 & 100.0 & - \\
\hline \multicolumn{6}{|l|}{ Endemic Area } \\
\hline Yes & 37 & 28.0 & 96 & 72.0 & 1.00 \\
\hline No & 29 & 43.0 & 38 & 57.0 & $1.56(1.06-2.29)$ \\
\hline \multicolumn{6}{|l|}{ Family Income (SM) } \\
\hline$\geq 1 \mathrm{sm}$ & 19 & 27.5 & 50 & 72.5 & 1.00 \\
\hline$<1 \mathrm{sm}$ & 47 & 36.0 & 83 & 64.0 & $1.31(0.84-2.05)$ \\
\hline \multicolumn{6}{|l|}{ Building material } \\
\hline Masonry & 36 & 30.8 & 81 & 69.2 & 1.00 \\
\hline Wood & 15 & 37.5 & 25 & 62.5 & $1.22(0.75-195)$ \\
\hline Masonry and wood & 10 & 28.6 & 25 & 71.4 & $0.93(0.51-1.68)$ \\
\hline Black canvas/straw/leftovers & 5 & 62.5 & 3 & 37.5 & $2.03(1.11-3.71)$ \\
\hline \multicolumn{6}{|l|}{ House (walls on all sides) } \\
\hline Yes & 62 & 32.0 & 130 & 68.0 & 1.00 \\
\hline No & 4 & 50.0 & 4 & 50.0 & $1.55(0.75-3.19)$ \\
\hline \multicolumn{6}{|l|}{ Rooms/household } \\
\hline$\geq 5$ & 25 & 36.0 & 45 & 64.0 & 1.00 \\
\hline$<5$ & 41 & 31.5 & 89 & 68.5 & $0.88(0.59-1.32)$ \\
\hline \multicolumn{6}{|l|}{ People / household } \\
\hline$<4$ & 32 & 31.0 & 72 & 69.0 & 1.00 \\
\hline$>4$ & 34 & 35.0 & 62 & 65.0 & $1.15(0.78-1.71)$ \\
\hline \multicolumn{6}{|l|}{ Bathroom location } \\
\hline Inside the house & 28 & 29.0 & 68 & 71.0 & 1.00 \\
\hline Outside the house & 38 & 36.5 & 66 & 63.5 & $1.25(0.84-1.87)$ \\
\hline \multicolumn{6}{|l|}{ Bath location } \\
\hline Bathroom (inside the house) & 51 & 32.0 & 110 & 68.0 & 1.00 \\
\hline River/dam/lake & 15 & 38.0 & 24 & 62.0 & $1.21(0.77-1.92)$ \\
\hline \multicolumn{6}{|l|}{ Where you sleep } \\
\hline Bed & 64 & 33.0 & 131 & 67.0 & 1.00 \\
\hline Hammock & 2 & 40.0 & 3 & 60.0 & $1.22(0.41-3.63)$ \\
\hline
\end{tabular}

The prevalence of malaria reported in 2005 was higher and statistically significantly associated with people that were 32 to 59 years of age. 
Table 2. Knowledge regarding malaria and the prevalence rate of malaria reported in 2005. Vale do Amanhecer settlement, municipality of Juruena, Mato Grosso, 2005.

\begin{tabular}{|c|c|c|c|c|c|}
\hline \multirow{3}{*}{ Variables } & \multicolumn{4}{|c|}{ Reported Malaria - 2005} & \multirow{3}{*}{ PR (95\% CI) } \\
\hline & \multicolumn{2}{|c|}{ Yes } & \multicolumn{2}{|c|}{ No } & \\
\hline & $\mathbf{n}$ & $\%$ & $\mathrm{n}$ & $\%$ & \\
\hline \multicolumn{6}{|l|}{ Knows how malaria is caught } \\
\hline Yes & 54 & 38.3 & 87 & 61.7 & 1.00 \\
\hline No & 12 & 20.0 & 47 & 80.0 & $0.53(0.31-0.92)$ \\
\hline \multicolumn{6}{|l|}{ How malaria is caught } \\
\hline Mosquito & 46 & 41.0 & 66 & 59.0 & 1.00 \\
\hline River bank/stream/dam & 4 & 27.0 & 11 & 73.0 & $0.65(0.27-1.55)$ \\
\hline Others & 4 & 25.5 & 10 & 68.5 & $0.70(0.30-1.64)$ \\
\hline Does not know & 12 & 20 & 47 & 80.0 & $0.50(0.51-0.85)$ \\
\hline \multicolumn{6}{|l|}{ Where the mosquito comes from } \\
\hline Still water & 28 & 43.0 & 37 & 54.0 & 1.00 \\
\hline Forest /river/stream & 8 & 61.0 & 5 & 39.0 & $1.43(0.86-2.39)$ \\
\hline Other (garbage, cesspits, etc.). & 10 & 29.0 & 24 & 71.0 & $0.68(0.38-1.23)$ \\
\hline Does not know/did not mention the mosquito & 20 & 23.0 & 68 & 77.0 & $0.53(0.33-0.85)$ \\
\hline \multicolumn{6}{|l|}{ Time that the mosquito bites } \\
\hline $\begin{array}{l}\text { Very early in the morning and late in the afternoon } \\
\text { "boquinha da noite" }\end{array}$ & 19 & 26.0 & 55 & 74.0 & 1.00 \\
\hline All day/all night & 27 & 71.0 & 11 & 29.0 & $2.77(1.79-4.29)$ \\
\hline Doesn't know/did not mention the mosquito & 20 & 23.0 & 68 & 77.0 & $0.89(0.51-1.53)$ \\
\hline \multicolumn{6}{|l|}{ Where malaria is caught } \\
\hline River/forest & 12 & 26.0 & 34 & 74.0 & 1.00 \\
\hline Gold mining & 9 & 26.0 & 26 & 74.0 & $0.99(0.47-2.07)$ \\
\hline House/Backyard & 8 & 38.0 & 13 & 62.0 & $0.90(0.41-1.96)$ \\
\hline Others (any other place) & 25 & 64.0 & 14 & 36.0 & $2.46(1.43-4.22)$ \\
\hline Does not know & 12 & 20.0 & 47 & 80.0 & $0.78(0.39-1.57)$ \\
\hline
\end{tabular}

Table 3. Individual practices of exposure and protection about malaria and malaria incidence in 2005, Vale do Amanhecer settlement, Municipality of Juruena, Mato Grosso, 2005.

\begin{tabular}{|c|c|c|c|c|c|}
\hline \multirow{3}{*}{ Variables } & \multicolumn{4}{|c|}{ Reported Malaria - 2005} & \multirow{3}{*}{ PR $(95 \% \mathrm{CI})$} \\
\hline & \multicolumn{2}{|c|}{ Yes } & \multicolumn{2}{|c|}{ No } & \\
\hline & $\mathrm{n}$ & $\%$ & n & $\%$ & \\
\hline \multicolumn{6}{|c|}{ Where you usually are early in the morning } \\
\hline Inside the house & 17 & 31.0 & 37 & 69.0 & 1.00 \\
\hline Backyard/corral & 37 & 31.0 & 82 & 69.0 & $0.99(0.61-1.59)$ \\
\hline Garden/field & 12 & 44.0 & 15 & 56.0 & $1.41(0.79-2.51)$ \\
\hline \multicolumn{6}{|c|}{ Where you usually are in the afternoon } \\
\hline Inside the house & 21 & 26.0 & 59 & 74.0 & 1.00 \\
\hline Backyard & 31 & 33.0 & 62 & 67.0 & $1.27(0.80-2.02)$ \\
\hline Garden/field & 13 & 59.0 & 9 & 41.0 & $2.25(1.36-3.73)$ \\
\hline Others (church/neighbor) & 1 & 20.0 & 4 & 80.0 & $0.76(0.31-4.57)$ \\
\hline \multicolumn{6}{|l|}{ Time when you usually have a bath } \\
\hline Afternoon (before 5 o'clock) & 8 & 18.0 & 36 & 82.0 & 1.00 \\
\hline Evening (at twilight) & 58 & 37.0 & 98 & 63.0 & $2.04(1.06-3.95)$ \\
\hline \multicolumn{6}{|l|}{ Use of mosquito net } \\
\hline Yes & 7 & 39.0 & 16 & 61.0 & 1.00 \\
\hline No & 59 & 33.0 & 118 & 67.0 & $1.10(0.47-1.43)$ \\
\hline
\end{tabular}


laria in economically active age groups was also observed in studies carried out by Alves et al. ${ }^{9}$ and Atanaka-Santos et al. ${ }^{3}$. In our study prevalence seems to be related to the period of life in which there is greater work activity in the field and in gold mining areas in which individuals are exposed to conditions with the highest density of vectors. Also, some studies have shown that immunity develops through cumulative exposure to transmission ${ }^{10}$ and age may possibly influence the development of protective immunity against malaria, regardless of past exposure ${ }^{11}$.

The prevalence of malaria in individuals that worked in mining activity was higher than observed among the house workers. The relationship between malaria and mining activity was verified in a study conducted in a gold mining community in the state of Pará, Brazil ${ }^{12}$. Some authors highlighted that the intensity of transmission becomes stronger when there is a combination of settlements and gold mining areas. These conditions are found in the Vale do Amanhecer settlement, where since the beginning of mining in the environmental reserve of the settlement in 2003, an increase in malaria cases has been reported ${ }^{13-16}$.

Considering the individuals from non-endemic areas the prevalence was $56.0 \%$ higher than those that came from endemic areas. These people are more vulnerable because they usually have lower immunity and little or inadequate knowledge about the disease ${ }^{17}$. However, it is important to note that the intensity of the transmission of the disease was not restricted to individuals from non-endemic areas, and an important prevalence rate was found among individuals from endemic areas. Of the individuals who worked in gold mining activities 100\% were from endemic areas, of which $89.0 \%$ reported having had more than four malarial episodes prior to 2005. The time living in endemic area is strongly associated to the number of episodes of malaria ${ }^{18}$.

Regarding housing conditions, individuals who lived in wooden houses and shacks made of black canvas had a higher prevalence, suggesting that these types of housing construction favor the transmission of malaria. Some studies reported that wooden houses and huts of canvas do not represent real barriers between the household and the external environment ${ }^{13-19}$.

With respect to individuals' knowledge about the mechanisms of malaria transmission, a higher prevalence was found among individuals that correctly reported that malaria is transmitted through mosquitoes. However, with respect to knowledge about the form that the vector transmitted the disease, the highest prevalence was statistically significantly associated with individuals who said that mosquitoes bite at any time and that malaria can be transmitted anywhere. When individuals do not know the time of the highest mosquito activity or the areas of concentration and reproduction, then they probably do not adopt protective and preventive measures to avoid the disease.

These results indicate that knowledge about the mechanism of disease transmission among respondents was not complete, thereby exposing them to a greater risk of getting the disease. A similar situation was found in a research about malaria transmission conducted on the Machadinho Project, Rondônia State, Brazil ${ }^{17}$. Several studies found a higher incidence of malaria that is, more susceptibility, among individuals with inadequate knowledge about the mechanisms of malaria transmission and the preventive measures $^{20-26}$.

Individuals who believe that mosquitoes bite at any time and that malaria can be caught anywhere probably disregard basic preventive measures and do nothing to protect themselves from exposure to mosquitoes ${ }^{27}$.

Among individual practices and malaria reported in 2005, despite the high percentage (70.5\%) of individuals that reported that they knew how the disease is transmitted, inadequate practices existed and were an important factor in the incidence of malaria in 2005 . These practices primarily included remaining in the garden/field or having a bath after 5 P.M. The prevalence was higher in individuals who engaged in daily activities at the time of highest mosquito density (very early in the morning and in late afternoon after 5). Individuals who answered to be out in the field during times of high mosquito density had a higher prevalence when compared to those that stayed at home. In individuals who reported having a bath at twilight, the prevalence of malaria was 104\% higher than in those bathing before 5 P.M.

A study carried out in the municipality of Guarantã do Norte, Mato Grosso State ${ }^{28}$, observed a strong association between malaria and gold mining. In this study, an association among these variables was also found, although the confidence interval is very wide, possibly could be a bias, which is characteristic of a convenience sample.

Despite, the miners' occupation was reported in a small number by the interviewees this factor was the most important one associated with the occurrence of malaria in the settlement in 2005, 
and it is important to consider that usually in this region the settlers may have both activities (agricultural and gold mining). Furthermore, gold mining activities usually is the secondary activity that complements the family income ${ }^{13-15}$, and it may not have been reported by the interviewees because it was not characterized as the main activity, being this exposure underestimated in our study.

It should also be noted that the Vale do Amanhecer was originally intended for the settlement of farmers. The mining activity developed marginally and generated problems in order to receive financial funds from the government programs such as PRONAF (National Program for Strengthening of Family Agriculture) and FETHAB (State Fund for Transport and Housing), which were created to support families in agricultural areas. This could be another factor to be accounted for the underestimation of gold mining activity at the moment of the interview.

Thus, the prevalence is possibly related to the occupational activity (agriculture and mining), poor house construction (huts made of canvas, incomplete walls) and daily activities (bathing after 5 P.M.). However, we cannot dismiss the role of inadequate knowledge and ignorance about the mechanisms of disease transmission.

The prevalence of malaria in 2005 was expected to increase among individuals that did not know how malaria was transmitted. Presumably, with more knowledge, precautions to avoid the disease would be adopted. This study found that most of the respondents reported that they knew how the disease was transmitted, thus not showing an association between knowledge and pro- tective measures. It is also possible that participants know that malaria is caused by the bite of a mosquito; however they may not understand the role of the mosquito in the transmission of malaria ${ }^{22-29}$. Consequently, they do not establish a relationship between how malaria is transmitted and prevention and control measures.

Other factors may influence the distance between knowledge and practice of the people in the settlement, such as socio-economic status (low income, little education, poor house construction and sanitation). Individuals may expose themselves to risks out of necessity even though they are knowledgeable about the risk.

In this context, approaches based on individual and community participation and health education should be increasingly valued in addition to environmental actions and epidemiological and entomological surveillance in order to control the disease in this area ${ }^{8-30}$. It is also necessary to adopt measures that could reduce the social and economic inequalities in the settlement area.

It was not possible to take a random sample due to the lack of up-to-date population data reports about the settlement, therefore generalizations from these results should be done with caution. Even though, this study estimated the prevalence of malaria in a population of a settlement and the relationships between malaria prevalence and socio-demographic variables, knowledge and individual practices were examined. Factors such as miner occupation, living before in non-endemic areas, knowledge and inadequate practices in relation to the forms of transmission and prevention of the disease were associated with the occurrence of malaria in this area. 


\section{Collaborations}

The contributions of the authors were as follows: IM Ferreira participated in the manuscript conception, data collection, data interpretation, manuscript writing and revising; EM Yokoo participated in the overall study concept, manuscript conception, data analysis, data interpretation, writing and review; R Souza-Santos participated in the manuscript conception, data analysis, writing and revising; ND Galvão participated in the study design, data collection, manuscript conception, statistical analyses, writing and review; M Atanaka-Santos coordinated and participated in the overall study concept, supported the results discussion, writing and review. All of the authors contributed to the critical revision of the manuscript.

\section{References}

1. World Health Organization (WHO). Why tackle malaria? Malaria-At-A Glance Roll Back Malaria. Geneva: WHO; 2001. [serial on the Internet]. [cited 2001 Ago 10]. Available from: http:/ /www.who.org/tdr

2. Barata RBC. Malária e seu Controle. São Paulo. São Paulo: Hucitec; 1998.

3. Atanaka-Santos M, Czeresnia D, Souza-Santos R, Oliveira RM. Epidemiological trends of malaria in the State of Mato Grosso, from 1980 to 2003. Rev Soc Bras Med Trop 2006; 39(2):187-192.

4. Mato Grosso. Secretaria de Estado de Saúde (SES). Coordenadoria de Vigilância Epidemiológica/ Superintendência de Saúde Coletiva. Dados Básicos sobre Malária no Mato Grosso, período 1990 a 2005. Cuiabá: SES; 2005.

5. Instituto Nacional de Colonização e Reforma Agrária (INCRA). Dados do Assentamento de Vale do Amanhecer - Juruena-MT. Superintendência Regional de Mato Grosso. Cuiabá: INCRA; 2006.

6. Mato Grosso. Anuário Estatístico de Mato Grosso 2004. Secretaria de Planejamento e Coordenação Geral Cuiabá 2005 [serial on the Internet]. [cited 2008 Jan 20]; 26:[about 710 p.]. Available from: http:/ /www.anuario.seplan.mt.gov.br/2004/

7. Torres TZG. Amostragem. In: Medronho RA, Carvalho DM, Bloch KV, Luiz RR, Wernek GL, organizadores. Epidemiologia. São Paulo: Atheneu; 2003. p. 283-294.

8. World Health Organization (WHO). The malaria manual: guidelines for the rapid assessment of social, economic and cultural aspects of malaria. Genebra: WHO; 1994. [serial on the Internet]. [cited 2004 Out 10]; Available from: http://www.who.int/tdr/ publications/publications/malaria-manual.htm

9. Alves MJCP, Mayo RC, Donalisio M Rita. History, epidemiology and control of malaria in Campinas region, São Paulo State, Brazil, 1980 to 2000. Rev Soc Bras Med Trop 2004; 37(1):41-45.

10. Baird JK. Host age as a determinant of naturally acquired immunity to Plasmodium falciparum. Parasite Immunol 1995; 11(3):105-111.

11. Baird JK. Age-depend characteristicsmof protection versus susceptibility to Plasmodium falciparum. Parasite Immunol 1998; 92(4):367-390.

12. Santos EO, Loureiro ECB, Jesus IM, Brabo E, Silva RSU, Soares MCP, Câmara VM, Souza MRS, Branches F. Diagnosis of Health Conditions in a Pan-Mining Community in the Tapajós River Basin, Itaituba, Pará, Brazil, 1992. Cad Saude Publica 1995; 11(2):212-225.

13. Barbieri AF. Uso antrópico da terra e malária no Norte de Mato Grosso, 1992 a 1995 [dissertação]. Belo Horizonte (MG): Universidade Federal de Minas Gerais; 2000.

14. Santos VR, Yokoo EM, Souza-Santos R, AtanakaSantos M. Socioenvironmental factors associated with the spatial distribution of malaria in the Vale do Amanhecer settlement, Municipality of Juruena, State of Mato Grosso, 2005. Rev Soc Bras Med Trop 2009; 42(1):47-53.

15. Sawyer DR. Malária and the enverinment. Brasília: Instituto Sociedade, População e Natureza (ISPN); 1992. [Documento de Trabalho; 13]. 
16. Souza-Santos R, de Oliveira MV, Escobar AL, Santos RV, Coimbra CE Jr. Spatial heterogeneity of malaria in Indian reserves of southwestern Amazonia, Brazil. Int J Health Geogr 2008; 7:55.

17. Sawyer DR, Sawyer DRO. Malaria on the Amazon Frontier: Economic and Social Aspects of Transmision and Control. Belo Horizonte: Cedeplar; 1987.

18. Duarte EC, Guerra HL, Gaudino MM, Fialho R, Castillo-Salgado C. Associação entre variáveis indicadoras de exposição à malária e títulos de $\operatorname{IgG}$ contra Plasmodium. In: III Congresso Brasileiro de Epidemiologia \& I Congresso Latino_Americano de Epidemiologia, Salvador: Anais Salvador, Associação Brasileira de Saúde Coletiva; 1995.

19. Sawyer DR, Sawyer DRO. The malaria transition and the role of social science research. Westport: Auburn House; 1992.

20. Agyepong IA, Manderson L. Mosquito avoidance and bed net use in the Greater Accra region, Ghana. J Biosoc Sci 1999; 31(1):79-92.

21. Aikins MK, Pickering H, Greenwood BM. Attitudes to malaria, traditional practices and bednets (mosquito nets) as vector control measures: a comparative study in five West African countries. J Trop Med Hyg 1994; 97(2):81-86.

22. Govere J, Durrheim D, Grange k, Mabuza A, Booman M. Community knowledge and perceptions about malaria and practices influencing malaria control in Mpumalanga Province. South Africa. SAMJ 2000; 90(6):611-616.

23. Pineda G, Agudelo CA. Perceptions, practice and attitudes concerning malaria in the Colombian Amazon region. Rev Salud Publica 2005; 7(3):339-348.

24. Rodríguez AD, Penilla RP, Henry-Rodríguez M, Hemingway J, Betanzos AF, Hernández-Avila JE. Knowledge and beliefs about malaria transmission and practices for vector control in Southern Mexico. Salud Publica Mex 2003; 45(2):110-116.
25. Ruebush TK, Kern MK, Campbell CC, Oloo AJ. Selftreatment of malaria in a rural area of western Kenya. Bull World Health Organ 1992; 73(2):229-236.

26. Tsuyuoka R, Wagatsuma Y, Makunike B. The knowledge and practice on malaria among community members in Zimbabwe. Cent Afr J Med 2001; 47(1):1417.

27. Palácios S, Sara E. Epidemiology of and risk factors of malaria by Plasmodium Falciparum (Welch, 1897) in the Jaén Sub-Region. 2000 - 2004 Cajamarca, Peru [tese]. São Paulo: Universidade de São Paulo; 2005.

28. Duarte EC, Fontes CJF. Association between reported annual gold mining extraction and incidence of malaria in Mato Grosso-Brazil, 1985-1996. Rev Soc Bras Med Trop 2002; 35(6):665-668.

29. Utarini A,Winkvist, Aulfa FM. Rapid assessment procedures of malaria in low endemic countries: community perceptions in Jepara district, Indonesia. Soc Sci Med 2003; 56(4):701-712.

30. Heggenhougen HK, Hackenthal V, Vivek P. The behavioural and social aspects of malaria and its control. An introduction and annotated bibliography. World Health Organization on behalf of the Special Programme for Research and Training in Tropical Diseases. TDR/STR/SEB [serial on the Internet]. 2003 [cited 2008 Jan 25]; 03(1): [about 226 p.]. Available from: http://whqlibdoc.who.int/hq/2003/ tdr_str_seb_vol_03.1.pdf

Artigo apresentado em 04/06/2011

Aprovado em 06/09/2011

Versão final apresentada em 28/09/2011 